\title{
Not So Dangerous Liaisons: Interstitial Subjectivities and the Autobiography of Arab Women
}

\author{
Samia Kholoussi ${ }^{1}$ \\ ${ }^{1}$ Ain Shams University, Cairo, Egypt \\ Correspondence: Samia Kholoussi, The Department of English Language and Literature, The Faculty of Arts, \\ Ain Shams University, Cairo, Egypt. E-mail: skholoussi1@gmail.com
}

Received: July 5, 2017 Accepted: September 19, 2017 Online Published: November 2, 2017

doi:10.5539/ells.v7n4p11 URL: http://doi.org/10.5539/ells.v7n4p11

\begin{abstract}
This research re-examines "cultural hybridity" from an Arab female standpoint. The concept is widely researched in post-colonial discourse, and in texts of bi-cultural Arab women, it is re-envisioned in the light of the specificity of their experience. Amidst a maze of proliferating theories, the study utilizes critical discussions in post-colonial discourse pertinent to the central argument namely; what does it mean to be hybrid for Arab women, and how do they perform cultural hybridity in their autobiographical writing? This study sets itself is to formulate a framework that allows us to talk about Arab women's autobiography in this context. It explores a space that would take into account ethnic and gender linked issues to investigate alternatives for Arab female self-identification in cultural hybrid contexts. For case study, I use Assia Djebar's Fantasia: An Algerian Cavalcade (1985) and Ahdaf Soueif's In the Eye of the Sun (1992) as texts as growing out of, and emerging against the culturally hybrid reality in which the autobiographical persona finds herself; a reality from which these self -representations evolve and authors begin to tell their stories. The study yields inferences regarding the potential of interstitial subjectivities as catalyst for agency, and a site of resistance and subversion. Cultural hybrid reality, for Arab women, is a site of contested and complex identities. It opens up a playing field of performative contestation in which identity thrives in ongoing endeavor to reformulate the debates on assimilation, integration, and identity politics within such a discursive territory.
\end{abstract}

Keywords: Arab women, autobiography, cultural hybridity, post-colonial discourse

\section{Introduction}

In Arab cultural experience, hybridity, the bequest of European colonization, produced contested and complex identities. This study examines the performance of hybridity in Arab female textual self-representation. It situates hybrid identities at the center of the Arab female experience. The researcher argues that, in this context, a more productive postcolonial reading consists in the interaction of different cultural streams as a task which needs not be undertaken at the expense of risking the loss of cultural signifiers. As case study, the researcher reads closely the semi-autobiography of the Algerian Francophone writer Djebar's Fantasia: An Algerian Cavalcade (1985) (henceforth cited as Fantasia), alongside the auto-fiction of the Egyptian Anglophone writer Ahdaf Soueif's In the Eye of the Sun (1992) (henceforth cited as EOS). The texts grow out of, and emerge against the culturally hybrid reality in which the autobiographical persona finds herself; it is a reality from which these self -representations evolve and authors begin to tell their stories.

Although these two narratives have been dealt with previously in a number of studies, building the researcher's analysis on alternative conceptual terrains is one way of relocating them to highlight unexplored areas. The introductory part will chart theoretical speculations on hybridity and autobiography. The second section on politics of location attends to each text's specific geo-political and historical contexts. The dialectics of the power of hybridity sheds an interesting light on Fantasia and EOS. The rest of the paper examines the impact of the ambivalence of the liminal positon on the politics of self-representation invoking agency and empowerment, and enabling/producing subversive and decolonizing forms.

In post-colonial discourse, cultural hybridity is profusely inspected. However, my objective in this essay is to scrutinize the concept from an Arab female standpoint, and in texts of bi-cultural authors in which the concept is re-envisioned in the light of the specificity of their experience. Amidst a maze of proliferating theories, the study utilizes critical discussions in post-colonial discourse pertinent to the central argument namely; what does it 
mean to be hybrid for Arab women, and how do they perform cultural hybridity in their autobiographical writing?

This study sets itself to formulate a framework that allows us to talk about Arab women's autobiography in this context. It explores a space that would take into account ethnic and gender linked issues to investigate alternatives for Arab female self-identification in cultural hybrid contexts. The study yields inferences that capitalize on Arab female consciousness in the interstices, and the construction and performance of identities claimed by two dissimilar cultures, and the potential of interstitial subjectivities as catalyst for agency, and site of resistance. The conclusion shows that for Arab women, cultural hybridity opens up a playing field of performative contestation in which identity politics thrives in ongoing endeavor to reformulate debates on acculturation, integration and occidentalism within such a discursive territory.

\section{Cultural Hybridity and Autobiography}

In a study investigating the performance of hybrid subjects in autobiography, Hallemeier (2011) underlines distinct yet overlapping visions that manifest hybridity's dual nature, thus revealing the potentials of the narrator's liminal position. Hallemeier bases her inferences on how hybridity functions within the writing and reading of autobiography on the theoretical narrative of Brian Castro dealing with performing the ambiguity of hybridity in autobiography. It depicts "autobiography as opposition" (222). The autobiographical element emerges as a "direct form of transgression" (114) of authority, perceived certainties, and restrictive notions of genre, self and nation. In contexts of hybridity, autobiographies, as Hallemeier shows, proffer deterritorialized perspectives that unfold a disaggregated identity uncontainable by rigid categories or a singular narrative identity Through invoking multiplicity, the "I" problematizes the idea of a unified subject writing a single truth, thus resisting classifying both author and writing. In Hallemeier's opinion, the intersectional lens of hybridity demonstrates the impossibility of the closure of any written text (119); identity discursively constructed frees the writer to look unencumbered to the past and to the future. Texts are imbricated in both remembering past oppression and envisioning an emancipated future, oriented towards pursuing a more just future. For Hallemeier, hybrid autobiographical subjects share the artist's position of marginality: it is painful but potentially liberating.

In his theory of multi-accentuality of discourse, Bakhtin (1981) attacks the notion of a separate self free of external influences. His approach applies to autobiography and becomes illuminating in the analysis of texts written by hybrid subjects wherein definitions of identity that excludes otherness are resisted and diversity within one voice is acknowledged. For Bakhtin, within a single unit, disparate voices are incorporated and contrary meanings are inscribed. On another plane, Werbner's (2015) speculations on the dialectics of cultural hybridity bear relevance to autobiography. She professes that the approach of a postmodern world celebrating difference through a consumer market offering endless choices of identities and subcultures, demonstrates the agency of cultural hybrids disturbing and in turn heightening reflexivity and double consciousness.

Identities multiply positioned are defined as intersectional. According to Sidonie \& Watson (2010), it is the task of autobiographers to navigate the shuttling of identities at a borderland they construct, and the hybridity of the narrator that emerges configures the performance of intersectional identities. Alternatively, Majaj (2006) infers that narratives endeavoring to capture the movement between worlds "often founder on cultural reductionism" (137). The complexities encountered in narrating cross-cultural experience and weaving a life out of the strands of cultural difference "is not an easy feat" (137).

In Maghrebi literature, Lebdaip (2007) detects an inextricable link of hybridity and autobiography. The syncretic nature of postcolonial experience triggers the telling of a complex personal experience. Lebdaip believes that Arab women writers lead this wave of literary creativity utilizing the "duality motif" in self-analysis for the purpose of (dis)covering and defining one's individuality and one's positioning in the course of history (35). In the age of globalization and migration, Golley (2003) argues against an authentic or culturally closed self. She declares, "I ... do not wish to divide myself into an authentic Arab self and an internally colonized other" (11). Deliberating on autobiographies by postcolonial Arab female hybrids, she finds in Spivak's positive essentialism "a strategy to reveal the internal differences" but admitting to a form of humanism "according to which all women and men of different cultures are entitled to express their humanity in their own varying cultural modes" (12).

Ostensibly, autobiographies of hybrid authors function as anti-essentialist theory embracing the dynamics of hybridity of joining and disjunction that catalyzes a subversive force troubling the established order. Writing hybridity requires receptivity to the experience of exclusion; standing outside of society and questioning it. Located inside and outside mainstream culture, the recognition of the ambiguity of hybrid identity is instrumental in escaping entrapment as the other and in forcing inclusion as a hybrid self. 


\section{Fantasia and EOS: "Politics of Location"}

Politics of location plays an important role in the writing of autobiographies. Given the borders of Djebar's and Soueif's politico-cultural formations, it behooves me to chart the specific context in which each text is produced and the self-narrator is situated. Admittedly, Smith (2010) states, "To understand the position from which one speaks, one has to take into account the specificities of historical and cultural location" (36-37). Significantly, Kaplan (1994) discusses textual "politics of location" as a way to examine the narrator's standpoint and its function in shaping perspectives. Inserting the context situates the autobiographical subject in her given role. Politics of location is crucial in shaping the construction of the autobiographical "I." It grounds the autobiographical subject in her specific geo-political location. As means of producing a "discourse of situation", the question of where we speak from points to sites of historisized struggles, and discursive factors governing the texts. Besides its contribution to deconstructing the hegemonic discourse, emphasis on local and cultural specificities of women's lives is effective in challenging homogenizing tendencies and offering alternatives. It points to the politics of location that the autobiographical subjects work in and against it.

Fantasia and EOS evoke the confrontations of the Arabs with the West whether in battlefields during the Islamic expansion into the heart of Europe in the eighth century and the Crusade wars which lasted from the eleventh till the fourteenth century, or with the cross-fertilization of cultural streams during the Islamic civilization in al-Andalus (756-1492) and the colonial condition spanning the nineteenth and early twentieth centuries. Concomitant rupture and communication produced culturally hybrid formations that varied according to historical conjunctures of three phases that emerge as guideposts in the Arab-occident encounter namely; the phase of mutual interaction before Europe acquired the connotations of exploitation, the phase when colonial intervention jarred with Arab autonomy, and a third constituting the period of national struggle to bring an end to colonization. In all cases, the interface gave birth to trends of transcultural creative writing.

In Fantasia and EOS, the distinction between the French territorial acquisition of Algeria (1830-1962) and the British colonial model in Egypt (1882-1952) had an impact on the process of cultural hybridization characterizing the texts respectively. The merchantile British colonialist cared most for the Suez Canal and the Egyptian cotton for the Lancashire factories, thus its onslaughts on cultural identity were less fierce. Moreover, while the assimilationist French considered imitation of their ways flattery, British "snobbish exclusiveness" (Chaudhuri 1954, as cited in Gordon 29) regarded imitation of themselves as "parody" (Lawrence 1935, as cited in Gordon 29).

Significantly, for the Egyptians successive foreign incursions throughout history were mere different external apparels under which indigenous reality remained intact. In Algeria, they displaced native linguistic signifiers. Messaoudi (1995)

The written culture of Algeria has always been in the language of the colonizer: Saint Augustine, whose native tongue was Berber, wrote in Latin, the language of the region's Roman colonizers; Ibn Khaldoun-Averroes, the 12th century philosopher - wrote in the language of the Arab colonizers; and contemporary authors like Kateb Yacine write in French, the language inherited from Algeria's last colonial era. (159-160)

On his part, Hourani (1991) remarks that Napoleon III saw that "Algeria was an Arab kingdom, a European colony and a French camp" $(55 / 271,1991)$ and the dilemma was how to reconcile these three elements. In the entire Maghreb region, Algeria suffered most acutely policies of French acculturation given the persistence to de-Arabize and incorporate the nation into French territory. According to Gosnell (2002), the rhetoric of assimilation in colonial Algeria reflects the complex nature of the metropole /colony relationship (6). Gordon (1989) notes, "Algeria remains poised uneasily between Mecca and Paris" (138). The dispute over Algeria's bi-cultural and bi-lingual status had been a subject of heated controversy among indigenous intelligentsia. On examining articles in the Algerian French language newspapers, Gosnell finds that they articulated the ambiguous nature of identity in colonial Algeria; subscribing to both indigenous and French norms (105). Farahat Abbas, in 1936, advocates an "asssimilation-ist" attitude and the need to maintain traditional culture and Moslem legal status. Zenati's editorials reiterated that "Algeria must become French" (quoted in Gosnell 2002, p. 113), nevertheless Islam should not be an impediment. Even as French rule was approaching its end and intellectuals and activists undertook to conceptualize an identity embodying an Algerian national consciousness, their proclamations were reticent about breaking with France and French cultural identity.

On another scale, Hourani (1962) invokes the eyewitness account of Al Jabarti (1756-1825) who lived in Egypt when the army of Bonaparte landed in 1801. The events Al Jabarti reports convey an ambivalent attitude towards western impingement on Egyptian reality acknowledging the achievements of "the French savants" yet heeding the imminent danger of "non-Moslem rule" (Hourani, 51). The first group of Egyptian intelligentsia produced by 
the scholarly missions which Mohammad Aly (1805-1848) sent to France in 1826 revealed a similar stance; Europe possessed the imagination of the literati but its ethos was incompatible with Arab thought. During the latter half of the nineteenth century, cultural leadership passed from conservative religious leaders to reformists like Tahtawi's (1801-1873), Al Afghani (1839-1897) and Abdouh (1849-1905) who conjoined native and foreign cultures. The trends they initiated reflected the chronic dilemma of how to conduct reforms along the lines of the West while remain true to authentic culture.

With the onset of British colonization, the relationship with the West was complicated for the Egyptian intellectual. The exhilarating effect of the contact jarred with the barbaric practices in colonial territories. The result is a range of polemics fluctuating between idolizing cultural heritage, and imitating Europe as the only way to bring the nation out of its slumber. Basing his commendation of the West on the cyclical nature of historical evolution put forth in the Qur'an, Al-Nadim (1845-1896), the fiery orator of his day, states, "For now they are the ones doing all the inventing and setting the rules: the good is what they say is good and the bad what they say is bad" (104). Each group of people assumes its hour upon the stage: once upon a time it was the East now it is Europe's turn.

With the conditional independence (1936) that legitimized British colonial presence in Egypt, several reformers urged the nation to take advantage of the Western civilization; to "benefit from it to advance the Arab nation" and create a new reality suited to local needs (Hourani 1962, as cited in Elsadda, 2008, p. 109). The atrocities of the Second World War produced a dilemma; "How to reconcile borrowing from the West with its ugly colonial face? ... How [to] borrow from the West and fight it at the same time ...?" (Elsadda, 2008, p. 109) Once claims of human advancement became questionable, reformers were "plagued by a sense of threat ... that this tyrannical ... Other would inevitably have to be resisted," and, as Elsadda (2008) maintains further, the perplexity about "what do we take and what do we leave? - assumed a tragic significance" (110).

In modern Arabic literature, the trend of rapprochement with the West is most aptly manifested in ego-documents. The confrontation has been an enunciative site. Van Leeuwen (1998) posits that "the other serves in constructing a self-image ... contrasting with and/or supplementing [it]" (27-28). Self-image is formed in the processes of interaction and cannot exist without some related image of an "other". Grunebaum (1962) states that "readiness to open ... oneself to an encounter with reality ... allows us to exploit the alien experience in the adjustment of our own" (34). Narratives in the context of cross cultural experience divulge a variety of authorial positions ranging from alienation and friction to a stance of dual allegiance and a struggle to resolve inconsistencies.

For Arab women who drank from the springs of native and western heritage and whose sensibilities partake of the tributaries of both cultures, self-narratives juxtapose multiple realities and in the process, capture the complexity of being Arab, female and a third world writer. In her discussion of pioneering female production, Shaaban (2009) notes that Afifeh Karam's Badi' a wa Fu'ād (1906) is the first published novel in Arabic that deals with cultural clashes between East and West. In al-Maghreb, Beur women's personal narratives stand out prominently as representative of hybrid writers straddling two worlds, and their struggle gives rise to contrasting conceptions of home.* In al-Mashriq and Bilad ash-Sham, processes of cultural intermixing in female autobiography take a different turn that is aptly articulated by Ahmed (1999) "We always embody in our multiple shifting consciousness a convergence of traditions, cultures, histories coming together in this time and this place and moving like rivers through us" (25). Salme's An Arabian Princess between Two Worlds (1886) is a trailblazer followed by several autobiographical outpourings that represent a wave that participates in a pool of different legacies.

The above overview of the Arab scene of cultural hybridity brings me to a consideration of the interstices as a site of agency and resistance in Fantasia and EOS.

\section{Politics of Self-representation in the Interstices: Empowering and Subversive Potential}

In cultural crossing, identity politics is one of the most pressing issues. The interstitial identity engages with the restless process of identification. For Papastergiadis (1997), only with "a consciousness of ... oscillation between different positions and perspectives, that hybridity can offer a new understanding of identity" (15). In his theory of the dynamics of cultural exchange, Papastergiadis calls attention to the need to understand "both the disturbing anxiety generated by cultural hybridity and [its] productive and enabling force" (2000, p. 182). Inhabiting the rim of the in-between catalyzes an energy field of different forces of separation and connection. The lucrative impact of merging two cultures is discussed by Bakhtin (1981) in terms of forms of hybridity in which dialogically situated perspectives enable a contestatory activity that possesses "energy and open-endedness" (361) and the hybrids produced are "pregnant with potential for new world views" (360). 
In Djebar's Fantasia, the post-colonial Arab female subjectivity is claimed by the burden of a bi-cultural heritage. From the day she was escorted by her father to a French colonial school, "a double and contradictory sign reigns over [her] initiation (4)... Two different apprenticeships, undertaken simultaneously, land [her] in a dichotomy of location" (Djebar, 1993, p. 184). Henceforth, the autobiographical subject contracts a chronic disease of divided desire, suffering the anguish and perplexity of a split subject.

From the outset, the text sets the stage for a hybrid landscape. Djebar's title (originally L'Amour, La fantasia) epitomizes the bifurcated reality which informs the text's thematic and structural parallelism. The discipline of titlogy emphasizes the multi-functional power of the title as a paratextual category with designative and connotative functions that, as Genette (1988) argues, controls the thematic development, one's reading of the text, and intertextual or intercultural references (708). For Maiorino (2008), titles possess the capacity to connect the reader to the cultural and literary context of the writing as a whole; offering a perspective and demanding an interpretation. In this sense, Fantasia refers to a western musical composition unimpeded by a set form, and to a horseback performance in traditional Arab festivities. In a like manner, the autobiographical subject is a composite of two "consciousnesses" at once a participant in the French culture to which the narrator owes her intellectual initiation, and an offspring of the indigenous legacy that constitutes an umbilical cord impossible to rupture.

The epilogue returns to the title mentioning Eugene Fromentin's painting. His canvas of scenes of tragic consequences resurrects a fantasia of the Hajouts tribe in which festivity turns into a tragedy due to the fury of a warrior who "jilted by Haoua (his lover), he strikes her down ... The charger kicks her in the face and she falls mortally wounded" (Djebar, 1993, p. 225). Moreover, the painting portrays the fighting after the capture of the city, "the real tragedy of the Fantasia" (Djebar, 1993, p. 225), as a gesture in honor of resistance of an Algerian tribe and in recognition of the decimation of bodies left dying slowly in the sun as the French's "horse's hooves pound into the distance" (225). In this respect, Taha (2000), reflecting on the power of the title, depicts it as pre-text, the part which is the first to welcome the reader and is separated from the body of the text. And, in essence, it also features as post-text being the last station to which the reader returns after his contact with the body of the text (66).

The narrative trajectory of Djebar's (1993) text is informed by the dialectic of colonial encounter. Acquiescence and resistance exist in a fluctuating relationship. The narrator declares, "Even where I am composing the most commonplace of sentences, my writing is immediately caught in the snare of the old war between two peoples. So I swing like a pendulum" (216). Two different versions of reality are communicated by the two cultures, and often convey opposing messages. She writes, "I do not realize ... that, in the conflict between these two worlds, lies an incipient vertigo" (185). The narrating self emerges as a tragic hybrid. Syncretism is a painful negotiation generating a sense of lack, the anxiety of division and a yearning for an autonomous identity.

Cultural schism, articulated so forcefully in Fantasia, gathers strength in the issue of language. The text conveys a trend that prevailed among Algerian reformers and literati after Independence when the use of French was discouraged and Arabic became the language of state. Ambivalence vis-à-vis the bilingual issue, Armitage (2000) notes, has "delayed the emergence of genuine Maghrebi Francophone literature" (45). The question what constitutes Maghrebi literature is contested by Maghrebis writing in French and those writing in Arabic, each claiming the right to represent Maghrebi culture. Several educational leaders, as Gordon (1989) maintains, especially Mostefa Lacheraf and Ahmed Ibrahimi, set "Arabization" as the goal, but they do not want to "cut off Algeria's youth from access to modernity" (137).

It is a condition fraught with discrepancies: for those indoctrinated in French-ness, using western language is fait accompli and, as Gordon contends, jettisoning it after independence is a retrograde step (137). Boudjedra (1969) admits its seductive power saving the writer from the constraints of conformity to tradition, and restraints on self-expression (as cited in Armitage, 2000, p. 51). For the advocates of authenticity, favoring French disrupts endeavors of decolonizing the mind, and obstructs the emergence of national literature. Chraibi (1954) believes that French can only become integral to an authentically Algerian culture by re-fashioning it to embody the essence of Maghreb (as cited in Armitage, 2000, p. 48). Questing for a nation that accommodates the divisions of Francophone writers, Khatibi (1983) comes up with the plurilingualism concept: with roots in two cultures, Maghreb can mingle both achieving diversity without losing its identity. A dual sense of engagement is favored by Yacine (1956) as propitious in building bridges between the civilizations both languages represent (as cited in Armitage, 2000, p. 49).

Ironically, the "mission civilatrice" bequeathed a legacy of cultural imperialism inflicting on Maghrebi writers 
in French the scars of betrayal; Armitage wonders if it is possible "they can be rooted in a culture that destroyed their own" (62). In Fantasia the speaking subject is caught in a nomadic condition between the "long-lost mother-tongue" (125) and French, a step-mother tongue. The association of French with the yoke of colonial oppression is a haunting nightmare. It is, the narrative voice shrieks, a "tunic of Nessus (217) ... its flowers ... are the flowers of death (181)... it became a dagger threatening" (126). Given the memories of carnage and massacres, embracing it is a betrayal which weighs heavily on the conscience. She remarks, "This language was formerly used to entomb my people; when I write it today I feel like the messenger of old, who bore a sealed missive which might sentence him to death or to the dungeon" (215). More painful to her is the inseparability of French language and her identity. In Fantasia, subjectivity is inscribed and articulated in the very language which dismembered cultural identity and subjected native signifiers to denigration. The narrator declares, "By laying myself bare in this language I start a fire which may consume me" (215). Thus, dissonance erupts between the medium of representation and the object of representation.

For the autobiographical subject, renunciation of native idiom and practice triggers a sense of internal exile and fear of up-rootedness. Living under the auspices of her western education, she expresses her ostracism from the lore of ancestors: "I discover I have no memory of Arabic love-songs" (215). The drama of privation is enacted in family gatherings during which, she broods; "I had lost the knack of sitting cross-legged: this posture ... indicated that I was one of all the women and shared their warmth" (127). She pines for the sense of participation and sharing. In fact, even when opting for foreign verbosity, one is only nourished by one's own because one grasps the reality which formed it. It is the intimate space of Bachelard's "espace heureux". This is expressively conveyed by the narrator, "I speak of the Arabic script; to be separated from it is to be separated from a great love ... all other... scripts (French, English, Greek) seem only to babble, are never cathartic" (181). Arabic remains for her the forbidden paradise.

At the other end of the spectrum, the association with French opens a flood-gate within her. It is a locus of self-affirmation through which she finds her own personal voice. She reflects, "When I write and read the foreign language, my body travels far in subversive space" (184). Metropolitan language renders indigenous reality accessible to a wider readership. Hooks sums it up aptly, "this is the oppressor's language / yet I need it to talk to you" (295). Alternatively, Soraya Antonius comments that the writer utilizes the resources of bilingualism in confronting the Western Other who once used politico-military force to subjugate her culture (267). Fantasia displaces the former usage of western language as a weapon to mortify and humiliate, and wields it as a means of denunciating colonial history. The autobiographical persona makes herself a subject in a linguistic arena that had formerly inscribed her as object. She indulges in gratifying a growing need to be seen and to have an audience declaring, "The word is a torch" (62); without her access to the colonizer's language and hence western academia, she could not have achieved recognition as a creative writer.

Additionally, she is cognizant of a power that, for native women, is unattainable. Armed with the written word, which is an endowment of her French education, she launches "an unprecedented women's battle" (13), and announces, "I seize this living hand, hand of mutilation and of memory, and I attempt to bring it the qalam" (226). She is spared the stifling enclosures of female peers suffering a legacy of silencing proscriptions. Frantz Fanon remarks that "To speak a language is to take on a world, a culture" (38), and thus her adopted culture enables her to circulate in public space unencumbered and achieve female visibility. Significantly, her transgression is a feat of accomplishment; she states ecstatically: "As if the French language ... had eyes, and lent them me to see into liberty ... I could move freely ... annex the outdoors of my cloistered companions, for the matriarchs of my family who endured a living death" (181). Admittedly, the same colonial education could have been equally empowering for other women.

On another plane, the exploration of the power dynamics of hybridity in Sabine Mabardi's postulations posits that hybridization of cultures entails negotiating practices of powers of the hegemonic and the subaltern. Underpinning her argument is Bhabha's (1994) stance averring that interstitial agencies produced in the negotiation "find their voice in a dialectic that does not seek cultural supremacy or sovereignty" (as cited in Mabradi, 2000, p. 8). For Mabardi, such characterization eliminates essentialism and re-conceptualizes agency as ambivalent (15). In Trinh Minh-ha's discussion of alternative forms that transform dichotomous colonial and sexist discourses, difference is envisioned in a positive light as "a tool of creativity to question multiple forms of repression and dominance" (Minh-ha, 1988, p. 73). She focuses on exuberant possibilities in the boundary line separating identities from each other. In the constitution of subjectivity in the context of hyphenated identities and hybrid realities, Minh-ha states that "the insider steps out from the inside ... looks in from the outside ... Undercutting the inside/outside opposition ... moves about with ... two gestures ... affirming "I am like you" while persisting in her difference ... unsettling every definition of otherness" (72). 
In this regard, Soueif's EOS merges cultural streams while maintaining intact cultural specifics. For Asya al "Ulama, the autobiographical persona, self-validation is necessary before any integration with the western culture can take place. Her fledgling awareness is partly claimed by the affirmative power of authenticity (asala) and faithfulness to cultural signifiers. In England, staying connected is a pressing desire: "How can she be yearning for Cairo ... while she is actually here in the middle of it all? If it were a pool she would dive into it, but as it is, what can she do more than just be, just be here?" (EOS 780) Engagement with the West reinforces the attachment to indigenous reality and keeps it vibrant.

Egyptian identity, Hanna (1994) explains, is a totality of plurality. His pillar theory unfolds a palimpsest space in which vestiges of accumulative civilizations form the tapestry of the nation's cultural horizon. Historical pillars of Pharaonic, Greco-Roman, Coptic Christian and Arab Islamic implanted in geographical/cultural realms of the Arab world, Africa and the Mediterranean, are integrated with varying degrees in every Egyptian. Intellectuals pride themselves in a heritage encompassing a nexus of multiplicity of contexts and voices that are at once contestatory and dialogic. In EOS, a consciousness of constellation of cultures and ideologies extending deeply in history informs the politics of self-representation. Unlike a literary generation embracing essentialist formulations as buffer zone against anything foreign, Asya relates unencumbered to the West and it figures as a counterpart of her Arab background.

EOS proceeds from within the two cultures in conjunction. Western and native realities form confluent tributaries in the intellectual formation. Asya's England resonates with memories of and scenes from Egypt, and her Egypt reverberates with the influence of western tradition. The two worlds are seen in terms of each other as spaces of desire. In her English cottage, amid English fields, in the arms of an English lover, and with Anna Karenina, Middlemarch, and My Life as a Man on the bedside table, "The voice of Ummu Kalthoum, a whiff of incense, a trick of light, and she is ... hurrying home ... as the call for sunset prayers echoes distantly" (524). As she conjures up an image of a future husband, she makes sure that "he can listen to Mozart and Ummu Kalthoum" (782). In England, she looks at the sea and remembers Alexandria. Her walk along the embankment of the Thames triggers images of the Nile. As she seeks solace for her inner turmoil in the cathedral and the Bible, "she remembers women in Egypt ... at the Shrine of Al Sayyid al Badawi and ... at the shrine of St. George the Martyr ... kissing the cold metal, weeping ... begging for health ... for the return ... of a beloved son" (333). Asya thinks in terms of "the commonality of human experience beyond politics" (754) considering herself part of a great humanist tradition thriving in the profit accrued from the interplay of the two domains with their different historical experiences.

In Hanafi's (1992) theory of "occidentalistics", the ultimate objective is the liberation of both the self and the other from the imprisonment of the dyadic relation and shaking off the yoke of the image implanted by each on the other. Despite the disequilibrium in power-relations, the nature of cultural transfer is never one-sided. Intercultural import-export should allow for reciprocal influences and mutually productive exchange between East and West. In fact, Soueif's narrative is not motivated by rancor nor does it seek to detract from the value of the other, but aspires to restore the balance to human culture. In an imaginary conversation with an Englishman, the narrator invokes her heritage as Arab and female: "I haven't come to you ... empty-handed: I bring you poetry as great as yours but in another tongue, I bring you black eyes and golden skin and curly hair, I bring you Islam and Luxor and Alexandria and lutes and tambourines and date palms and silk rugs and sunshine" (512). On the other hand, she contemplates "the accoutrements of the Empire ... [and] does she not find it in her heart to feel resentment or bitterness ... but admiration for ... the graciousness and the harmony of the scene? ... she feels herself a part of all this? ... glad to show it all off ... as she would show off the pyramids or the mosque of Sultan Hassan" (512). The autobiographical persona comes to terms with the evils of the imperial exploitation, and emerges as part of the global intellectual ferment and seeks to contribute to it. Along these lines, Ashour (2001) lays out a scheme for a healthy process of transculturation and cultural pluralism in which we need to be selective in appropriating metropolitan modes of representation to protect an Arab distinctive cultural expression. She advocates a world village that, in maintaining the interaction of cultural tributaries and cultural diversity, sprawls like a tapestry with innumerable floral patterns where each flower has its own recognizable significance.

The inter-textual nature of $E O S$ locates self-representation in a dynamic milieu of diverse voices traversing the text. The migratory narrative consciousness is evoked through incorporations of citations from recognizable productions in eastern and western cultural tradition namely; the Qur'an, the Bible, folksongs, Middlemarch, Bob Dylan etc .... Situating the text in a system of references to other texts is instrumental in defining identity as cultures' in-between, superseding the dichotomous vision and meshing the two cultures. Furthermore, the narrative proceeds on two levels corresponding to the duality of consciousness mingling sense perceptions 
with random associations. An episodic structure allows for shifting points of view and the fluidity in streams of thought flitting backward and forward in time and space.

On a different scale, hybridity is experienced as a condition seething with instability. Debates of post-colonial theorists are preoccupied with the challenges that hybrid counter-energies pose to the mono-cultural Western theory. For Bakhtin (1981), the voices that hybrid spaces accommodate destabilize authority, thus constructing fertile fields for the act of revising settled hierarchies. The consciousness of the colonized of the subversive potential of hybridization enables acts of resistance that, as Bhabha (1994) professes, "turns the discursive conditions of dominance into the grounds of intervention" (111). For Bhabha, hybridity is a force that catalyzes subversion in sites of cultural difference such as liminality, ambivalence and mimicry. Double-voicedness in these spaces contests essentialism and disrupts mainstream totalizing projects. Nativist mimicry of colonial values, instead of resulting in compliance to and consolidation of colonial control, creates an "interrogatory, interstitial space" (Bhabha 3) in which the "other denied knowledges enter upon the dominant discourse and estrange the basis of its authority" (Bhabha, 114) and loses its univocal grip on meaning. The following section analyzes modes of oppositional strategies in the interstices as manifested in Fantasia and EOS.

In a culturally disinherited Algeria, autobiographical writing participates in archival research concerned with reclaiming to prominence a "contrapuntal" reading of the fall of Algeria (1830-1871) and its liberation (1958-1962). The autobiographical subject in Fantasia wields the condition of bi-lingualism in which she is ensnared to expand the narrative of Algerian history with accounts of French unofficial military correspondences as well as testimonies of nationalist Algerian combatants. The force of the dialogical structure, as Bakhtin (1981) contends, lies in its reference to the exchange between voices (360). Doubling the axis of the text juxtaposes viewpoints and layers them on each other palimpsestically.

According to Hutcheon (1988), narratives of historiographic metafiction are "self-reflexive ... yet ... also lay claim to historical events" (5). Moving from "private experience to public consciousness" aims at rendering inextricable the public and historical and the private and biographical" (94). Historiographic metafiction undermines the authority of historical sources through utilizing paratextual conventions of history and fiction such as selection and emplotment. Hutcheon contends that "there are only truths in the plural, and never one Truth; and there is rarely falseness per se, just others' truths" (110). In historiographic metafiction, re-writing the past seeks to "prevent it from being conclusive and teleological" (Hutcheon, 1988, p. 110); to question it in order to reconstruct it. Along similar lines, Fantasia presents an alternative narrative of Algerian history that also recovers the submerged presence of women in colonial resistance. The narrator slips into the antechamber of the past excavating obscured records of those who accompanied the French squadron:

I am practicing ... spelaeology ... opening a register of the dead ... Pelissier, butcher-and-recorder ... speaking ... on behalf of fifteen hundred corpses buried beneath el Kantara ... hands me his report and I accept this palimpsest on which I now inscribe the charred passion of my ancestors. (77-79)

Harking to the survivors' recollections and recovering epigraphs by long-forgotten witnesses, the text salvages denied truths from the inscriptions of the very perpetrators of ruthlessly committed incursions. Djebar (1993) delivers from oblivion details of forays and massacres that have for long observed the law of silence. The text, thus unmasks the irony of goodness and sense of duty proclaimed in military campaigns. In this regard, Mabardi (2000) suggests that "ambivalence or doublethink in hybridity produces a disavowal of colonial authority and a principle that destabilizes the historicity of the Western hegemonic discourse" (7).

Representational practices, the vehicle by which knowledge of unknown land and its foreign people is mediated, is manipulated by the colonial invader. Demonstrating the way the tendentious narrative of the colonizer is propagated, the narrator explains:

Thirty-seven witnesses ... will relate the events ... of July $1830 \ldots$ only three are ... viewpoints of the besieged ... Hordes of interpreters, geographers, ethnographers, linguists, botanists, diverse scholars and professional scribblers will swoop down on this new prey ... their publications will form a pyramid to hide the initial violence from view. (44-45)

Such account is juxtaposed with a native perspective confined, for long, to the margins. As an alternative narrative, it refracts the certainty surrounding colonial representation, and contributes to its de-legitimization:

A fourth man chronicles the defeat, adding his spadeful of words to help fill the paupers' grave of oblivion. I choose him from among the natives of the city: Hajj Ahmed Effendi, the Hanafite Mufti of Algiers ... 
Others will tell of these last moments (as Algiers prepares to live through its last night as a free city): a bach-kateb ... writes his account in Arabic. (39-42)

In the discourse of the colonized, the Algerians become the subjects of their own history. Inscribing subject-positions contends with colonial disavowal of native subjectivity. Native accounts take their place on the map of official reports and draw attention to what has been left out of institutional records.

Declaring that Eurocentric thinking is not the best representative of a multicultural world, Shohat's (2013) project of "unthinking Eurocentrism" calls attention to the transgressive potentialities and possibilities opened up by multicultural texts, and the participatory knowledge of non-European cultures. Rather than segregating historical periods and geographical regions into neatly fenced-off areas of expertise, she explores their interconnectedness, and threading communities together in relation without suggesting that their positionings are identical, thus seeing everything anew.

In reconstituting details of atrocities of carnage, the narrator locates herself in the battlefield with the dead and dying. The depiction captures the cannibalistic scenes in a personal way: "I, in turn, piece together a picture of that night ... this inferno which the French army gazed at in admiration ... cuts off fifteen hundred people and their cattle" (70-71). Near the end of the text, she admits to an indissoluble alliance with the macabre incidents:

The date of my birth is eighteen hundred and forty-two, the year when General Saint-Arnaud arrives to burn down the zaouia of the Beni Menacer, the tribe from which I am descended ... Before I catch the sound of my own voice I can hear the death rattles ... they provide my orchestral accompaniment. (217)

With the recovery of the Algerian experience, the autobiographical voice in Fantasia becomes collective, using colonizer's language to speak in the name of the victims of fumigations and all the native forces of resistance. The narrator reflects, "While I thought I was undertaking a "journey through myself"... I find myself progressively sucked down into the anonymity of those women of old - my ancestors" (216-17). With the move away from subjectivity to inter-subjectivity, fragments from life experience interweave with vignettes from the oral history of the Algerian female rural community at large. She admits, "Writing has brought me to the cries of the women silently rebelling in my youth, to my own true origins" (204). Shohat (2013) appropriately considers that the objection over the return to an essentialized past ignores the needs of indigenous people who feel they must go back to their lost origin for reasons of survival (as cited in Mabardi, 2000, p. 11). The re-connecting to the women of Algeria and re-constructing a female collective identity is fundamental to self-representation.

More specifically, in discussing the plural self in women's testimonies, Sommers (1988) explains how the "I" achieves her singular identity as an extension of the collective (108). The narrator adds her voice to those of her maternal ancestors, joins her story with theirs, drawing on a common structure of feeling. She recuperates terms of belonging to the female ancestry and forges personal links. It is, she writes, to "Mother, maternal grandmother and aunts ... (that) the little girl that is I runs desperately to find her voice" (194). A reversion to a cherished realm helps heal a self fragmented by the colonial experience and catalyze the reconciliation to a hybrid fate.

The narrator employs her verbal skills in Berber, Arabic and French to document female potential in Algeria's reality, and put an end to the negation that shrouds Algerian women. The process of inscribing female presence grapples with the anonymity enforced upon Algerian female experience by patriarchal impositions, and debunk western misconceptions about Arab women as "odalisque" in a harem.

Djebar (1993) renders her bi-culturality advantageous to women's cause. She declares, "I imagine you, the unknown woman, whose tale has been handed down by story-tellers ... For now I too take my place in the fixed circle of listeners ... I re-create you ... O ancestress of ancestress!" (189) She teases out from native and foreign sources "so many vanished sisters" (204) resurrecting their revolutionary role in battlefields of the French conquest and through the years of colonization and the war of independence. One French eyewitness attests to unflinching recalcitrance in their confrontation of the brutality of pillaging: "Even when ... submissive, (they are) not vanquished. (They do) not raise (their) eyes to gaze on (their) vanquisher. (Do) not recognize him. (Do) not name him. What is a victory if it is not named?" (56) When paraded in front of the conqueror, they "smear their faces with mud and even excrement ... they use the only mask at their disposal; they would use their own blood if the need arose" (56). The invaders confess to their cringing before such tacit armament. Quotes from the memoirs of a French official present a graphic depiction of the deaths of two women; "One ... lay dead beside the corpse of a French soldier whose heart she had torn out! Another had been fleeing with a child in her arms when a shot wounded her; she seized a stone and crushed the infant's 
head" (18) to save it from the fate of falling alive into the hands of callous soldiers. In a mixture of savagery and nobility, the spectacles evoke a sense of tragic triumph over an intrusive enemy.

One of the notable forms of critical historiography is history from below foregrounding silenced voices of those excluded from power. In Joan Scott's analysis of the relationship of women's history to established history, the following questions erupt: how have men and their actions become the sole representative of human history consigning women's contribution to forgetfulness. And, what effect would the perspective of female subject position have on practices of history? In order to meets the norms on which the discipline is erected, Scott cites Michel de Certeau's (1986) opinion that only women can write women's history and this would challenge claims of established history in telling the whole story, expose the hierarchy in historical accounts, and question the priority given to his-story as opposed to "her-story" (52).

For Arab female authors, this approach is instrumental in recovering the submerged presence of women. Integrating them into history, as Scott (2001) professes, is "required to correct the story" (56) ... for completeness or wholeness" (50), thus showing they fit into established histories and redressing the balance in official history. In the "part" entitled "Voices from the Past," Djebar pursues the goal of consolidating women's past through "compilation of data ... [with] evidence [they] influenced events ... took part in public life ... insist[ing] that private life has a public, political dimension" (Scott, 2001, p. 56). Fantasia retrieves long muted testimonies; the "shards of sounds which re-echo in the calm after the storm" (165). This segment of the text is based on taped interviews the author conducted in her native city, Cherchell, with surviving heroines who indulged in reminiscences of their feats in the liberation struggle. In this regard, orality plays a crucial role in the power structure implicated in the relationship of writing and speech; "Voices from the Past" endows the spoken word the same privilege which writing and graphic representation possesses. As oral narratives, these reminiscences exact the same legitimacy enjoined by formal reports and claim the same forcefulness relegated to written records.

On another plane, the subversive potential of the interstices in Soueif's auto-fiction emerges in the linguistic arena wherein the incorporation of Arabic in the English text creates a counter-language. Bakhtin's (1981) scrutiny of the mixture of languages within a text bears relevance. To him, the hybrid text "liberates cultural-semantic and emotional intentions from the hegemony of a single and unitary language" (367), and thus fractures the singular order by which the dominant code characterizes the other. In fact, the language of hybridity becomes the means for critiquing the monological language of authority.

$E O S$ embodies two different linguistic "consciousnesses" which intersect in a hybrid construction. The text demonstrates continual interaction through the inlaying of the English language with Arabic phrases. The process of linguistic mélange produces a space reflective of the interstices. In a confluence of utterances, Arabic words and adages enmesh in the English text and create a legible double-voiced discourse; namely, mulukhiyya (86), halawa (134), shisha (198), zaffa (251), zar ... galabiyya (274), Sett (271), "al ataba has filled with light" (198), "With Happiness and Progeny" (245), "O black day" (302), "the flesh on your shoulder is from his bounty" (291), and "May the rest be in your life ... Your life be long" (287). Even though each language embodies a view of the world that is peculiarly its own, the text conjures up a reality which is adapted to both linguistic domains. The "doubleness" of hybrid voices creates a language that is both the same and different. In fact, in postcolonial era, the linguistic over-determination is countered by linguistic negotiations emblematic of the hybrid, transnational and trans-cultural experiences of many Arab women writers.

In his study of the conventions and discourses in which selves and lives are represented in classical Arabic literature, Reynolds (2001) observes that "texts of hyphenated identities problematize the boundaries of the Arabic tradition" (7). In this sense, they challenge the notion of clear cut borders definable by language. However, Soueif declares in an interview that EOS "belongs to the Arab literary canon" (Show, "Talking Fiction" WBN. Oct. 15, 1994) thus fathoming a way by which native reality may be constituted in English language. Even if Soueif can't write in Arabic, she writes as an Arab; in the thought and speech rhythms of Arabic. Admittedly, the text reads English and sounds Arabic: a complex linguistic experimentation renders it an English text in terms of its lexical features and grammatical structure, yet in sense and texture, it is not purely English.

In post-colonial discourse, language represents a fundamental site of opposition and a space for cultural intervention through which hybrid intellectuals develop different ways of knowing and thinking. In the hands of Soueif, the English language refuses to be confined within the rules of its traditional usage. Made to bear the weight and texture of a different experience, it is modified to comply with native reality and local needs. In 
doing so, Ashcroft (1995) observes that "it becomes a different language" as such "writers ... construct an "English" which amounts to a very different linguistic vehicle from the received standard colonial "English"” (284). Soueif recreates the English language to express emotions which are not English but Arabic. EOS takes the English language elsewhere, populates it with other people's sensibilities, memories, histories, traditions and stories, and returns with it more integrated, comprehensive and inclusive.

In fact, incorporating non-English words to convey meaning disorients the English monolingual readers and jolts them out of their linguistic complacency. Hooks (1995) argues that using western language does more than addressing a dominant reality; "In the act of being patient as we hear another tongue we may ... disrupt that cultural imperialism that suggests that one is worthy of being heard only if one speaks in standard English" (300). Moreover, the yoke of the verbal interplay and linguistic shift forms a creative response to acculturation and constructs a preventive measure against the bait of absorption and assimilation implicated in cultural hybridization.

Soueif's Anglophone discourse is iconoclastic in other ways. EOS turns female corporality into a literary weapon to achieve power over discourse. In autobiographical projects, Smith (1993) observes the intersection of subjectivity and body is inevitable; in telling their stories, women articulate their bodies as well. Smith's study demonstrates how "the autobiographical subject carries a history of the body with her as she negotiates the autobiographical "I"' (22-23). Speaking the self is linked in important ways to speaking the experience of female physicality. EOS portrays scenes of conjugal sexual conflict and extra-marital liaisons. In a sense, the text becomes one of the major chronicles of sexual politics uncharacteristic of Arabic letters mainly due to its female authorship. It grapples with auto-censorship on taboo territories. The author evades the bludgeons of conservatives by hiding behind the metropolitan linguistic medium and its association with notions of making public and transgression of proscriptions. In this respect, Sa'adawi (1999) articulates the duress she suffers as a writer when narrating physical intimacies, "When I deal with sex, I lose my mastery over language. This is the case especially with Arabic ... In English I can write down the word penis as simple as that, but in Arabic is called the masculine rod, which sounds obscene. It is even worse when I write about the female sexual organs" (10). On another plane, Accad (1991) notes that in a conference in Tunisia, deliberations on issues of sexuality evoked the denunciation of politically active female participants. They relegate a secondary position to such discussions that need to be postponed until more exigent problems associated with food, shelter and job opportunities are resolved (241).

Although EOS shows how on a cultural scale, east and west can meet, and how a harmonious identity can evolve out of a dual cultural background, a similar level of rapport is unattainable when it comes to politics and gender relations. In England, Asya recognizes that misguided assumptions about Middle Eastern politics create an ineluctable rift. After the 1967 war, Asya reports a prevalent hostility: "They always have photographs of individual Israeli soldiers-girls too- looking ... like perfectly normal sympathetic people, while the Egyptians are always a dusty rubble ... you can never see any of their faces" (342). Discussing politics with western friends drifts them apart. They superimpose a partial interpretation on the political situation as the one and only valid truth (383-84), and reduce the argument to their own point of view solely. In other situations, she discovers that whereas she is fully educated about their culture and society, their knowledge about her world are gleaned, as Edward Said states, from "abstractions about the orient" (300). As she tries to translate a song to them, she finds it a ponderous task explaining to people who have no comprehension of her socio-cultural background. It needs "A page of footnotes for every line" (496-499) although it is a "language that a completely illiterate, uneducated woman would use to her child" (EOS 497). There is a rupture that is hard to heal. Despite an acknowledgment of a harmonious postcolonial present through a process of hybridization that happened to her naturally, she cannot disregard "a sinister, insidious colonialism implanted in her very soul ... that no rebellion can mitigate and no treaty bring to an end" (EOS 512).

Sexual liberation looms large as another juncture where Arab and Western cultures do not meet and fail to correlate. The West for Asya, the autobiographical persona, is "Romance", "Sex" and "Freedom" (EOS 460). She is impressed with the casualty of sexual relations. However, the extra-marital affair with an Englishman elicits mixed reactions of remorse and ecstasy. She is physically satiated yet deeply disturbed because "she, Asya al Ulama, is committing adultery" (540) ... the mighty adulteress ... the liberated, fulfilled, sensuous woman, the defiant femme de plaisir?" (EOS 543) Significantly, when she is asked to demonstrate some Arabic sounds unfamiliar to English speakers, she chooses "Haram" (sinful) for " $H$ ", "khiyana" (betrayal) for "kh" "Antar" (macho) for "ain". When she tries to articulate "Qur'an" to demonstrate the "q", the word does not come out and her mouth is dry (EOS 353-354). In fact, the ease with which Asya wades through both the 
eastern and the western cultural realms is disrupted on the political and sexual planes wherein negotiating differences reaches a stalemate.

\section{Conclusion}

Arab female autobiographical narratives concerned with what it mean to be hybrid and how one performs hybridity seeks to force inclusion and escape entrapment as the other. In the interstices, the construction and performance of identity hinges upon a relational process of differences and identification. On examining cultural hybridization in Arab female textual self-representation, the question erupts regarding the instrumentality of the autobiographical process in healing the fragmented narrating self and going beyond binary structures and repressive ideologies thus forming new paradigms.

In Fantasia and EOS, the "contestatory" cultural politics in the power of hybridity is at work enabling forms of subversion and invoking the complex dynamics of agency. Double-voicednesss of hybrid constructions and fluid practices of de-territorialized subjectivity disarm the dominant mainstream of its single voice opening it up to the world-view and presence of the other. In fact, Arab female textuality between two cultures embody systems of signification peripheral to the mainstream in multiple ways; namely, it is inscribed from a woman's vantage point, in a foreign language, from a non-European perspective and by Arab and / or third world citizen. Thus, it emerges as a counter-narrative in more than one sense.

In Fantasia and EOS, aesthetic creations that evolve from hybridized consciousness manifest lawami, (revelations), and urge a questioning of preconceived ideas in the light of new discoveries. Armed with isti'dad (the state of readiness), the experience expands the horizon of awareness and knowledge. For subjectivities occupying a position on both sides of the boundary, separate systems of signification that are interdependent yield an expansive experience and an effusive identity. Cultural interaction opens up a playing field of performative contestation in which Arab female identity thrives in the profit accrued from the interaction of different cultural streams.

\section{References}

Accad, E. (1991). "Sexuality and Sexual Politics: Conflicts and Contradictions. In C. Mohanty et al. (Eds.), Third World Women and the Politics of Feminism (pp. 237-250). Bloomington: Indiana University Press.

Ahmed, L. (1999). A Border Passage. New York: Columbia University Press.

Antonius, S. (2000). The Day of Outside Education. Alif: Journal of Comparative Poetics, 20, $257-268$. https://doi.org/10.2307/521949

Armitage, A. (2000). The Debate over Literary Writing in a Foreign Language: An Overview of Francophonie in the Maghreb. Alif: Journal of Comparative Poetics, 20, 39-67. https://doi.org/10.2307/521941

Ashcroft, B. (1995). Constitutive Graphonomy. In B. Ashcroft et al. (Eds.), The Post-Colonial Studies Reader (pp. 283-284). New York: Routledge.

Ashour, R. (2001). Sayadou al Dhakirat: maqalat naqdiyah (Chasers of Memories). Al Dar al Bayda': al Marqaz al Thaqafy al' Arabi.

Bakhtin, M. M. (1981). The Dialogic Imagination. Translated by Michael Holquist and Caryl Emerson. Austin: The University of Texas Press.

Bhabha, H. (1994). The Location of Culture. New York: Routledge.

Djebar, A. (1993). Fantasia: An Algerian Cavalcade. Translated by Dorothy Blair. London: Heinemann.

El Sa'adawi, N. (1999). A Daughter of Isis. London: Zeb Books.

Elsadda, H. (2008). Egypt. In R. Ashour, F. J. Ghazoul, \& H. Reda-Mekdashi (Eds.), Arab Women Writers A Critical Reference Guide 1873-1999 (pp. 98-161). Cairo: The American University in Cairo Press.

Fanon, F. (1967). Black Skin White Masks. Translated by Charles Lam Markmann. New York: Grove Press Inc.

Genette, G. (1988). Structure and Functions of the Title in Literature. Critical Inquiry, 14(4), 708-720. https://doi.org/10.1086/448462

Golley, N. (2003). Reading Arab women's Autobiographies: Shahrazad Tells Her Story. Austin: University of Texas Press.

Gordon, D. (1989). Images of the West: Third World Perspectives. Savage, Md: Rowman \& Littlefield Publishers. 
Gosnell, J. (2002). The Politics of Frenchness in Colonial Algeria, 1930-1954. New York: University of Rochester Press.

Grunebaum, G. E. V. (1962). Modern Islam: the Search for Cultural Identity. Berkeley: University of California Press.

Hallemeier, K. (2011). Writing Hybridity: The Theory and Practice of Autobiography in Rey Chow's The Secrets of Ethnic Abjection and Brian Castro's Shanghai Dancing. Antipodes, 25(2), 125-130.

Hanafy, H. (1992). Muqdima fi ilm al istighrab [Occidentalistics]. Beirut: al mu'asasa al jame'iya leldirasat wa al nashr wa altawzi'.

Hanna, M. (1994). The Seven Pillars of the Egyptian Identity. Cairo: General Egyptian Book Organization.

Hooks, B. (1995). This is the oppressor's language / yet I need it to talk to you: Language, a Place of Struggle. In A. Dingwaney \& C. Maier (Eds.), Between Languages and Cultures: Translation and Cross-cultural Texts (pp. 295-301). Pittsburgh: University of Pittsburgh Press.

Hourani, A. (1962). Arabic Thought in the Liberal Age, 1798-1939. London: Oxford University Press.

Hourani, A. (1991). A History of the Arab Peoples. London: Faber and Faber.

Hutcheon, L. (1988). A Poetics of Postmodernism: History, Theory, Fiction. New York: Routledge. https://doi.org/10.4324/9780203358856

Joyaux, G. (1980). Driss Chraibi, Mohammed Dib, Kateb Yacine, and indigenous North African Literature. In I. Boullata (Ed.), Critical Perspectives on Modern Arabic Literature (pp. 121-126). Washington D.C.: Three Continents Press.

Kaplan, C. (1994). The Politics of Location as Transnational Feminist Practice. In I. Grewal \& C. Kaplan (Eds.), Scattered Hegemonies: Postmodernity and Transnational Feminist Practices (pp. 137-152). Minneapolis: U of Minnesota Press.

Khatibi, A. (1983). Maghreb pluriel. Paris: Denoal.

Lebdaip, B. (2007). Yasmina, an Autodiegetic Character: Herstory and History. In N. A. Golley (Ed.), Arab women's Lives Retold: Exploring Identity through Writing (pp. 35-47). New York: Syracuse University Press.

Mabardi, S. (2000). Encounters of a Heterogeneous Kind: Hybridity in Cultural Theory. Critical Studies, 13(1), $1-20$.

Maiorino, G. (2008). First Pages: A Poetics of Titles. Philadelphia: Penn State University Press. https://doi.org/10.26530/OAPEN_625753

Majaj, L. S. (2006). Review of Into the Wadi, by Michele Drouart. Journal of Middle East Women's Studies, 2(2), 137-139.

Messaoudi, K. (1998). Unbowed: An Algerian Woman Confronts Islamic Fundamentalism. Philadelphia: University of Pennsylvania Press.

Minh-ha, T. T. (1988). Not You/Like You: Post-colonial Women and the Interlocking Questions of Identity and Difference. Inscriptions, 3(4), 71-77. $\quad$ Retrieved from http://ccs.ihr.ucsc.edu/inscriptions/volume-34/trinh-t-minh-ha/

Nadim, A. F. (Ed.). (1914). Sulafat al Nadim (A collection of articles by al-Nadim) vol.1. Cairo: Matba'at Hindiyya.

Papastergiadis, N. (1997). The Turbulence of Migration: Globalization, Deterritorialization and Hybridity. Cambridge: Polity Press.

Papastergiadis, N. (2000). Tracing Hybridity in Theory. In P. Werbner \& T. Modood (Ed.), Debating Cultural Hybridity: Multi-Cultural Identities and the Politics of Anti-Racism (pp. 257-281). London: Zed Books.

Reynolds, D. (2001). Introduction. In D. Reynolds (Ed.), Interpreting the Self: Autobiography in the Arabic Literary Tradition (pp. 1-14). Los Angeles: University of California Press.

Said, E. (1993). Culture and Imperialism. New York: Alfred Knopf.

Salme, S. (1993). An Arabian Princess between Two Worlds. Edited by E. van Donzel. Leiden: E.J. Brill. 
Scott, J. (2001). Women's History. In P. Burke (Ed.), New Perspectives on Historical Writing (pp. 43-70). Penn: Penn State University Press.

Shaaban, B. (2009). Voices Revealed: Arab Women Novelists, 1898-2000. Boulder: Lynne Reinner.

Shohat, E., \& Stam, R. (2013). Unthinking Eurocentrism: Multiculturalism and the Media. New York: Routledge.

Smith, S. (1993). Subjectivity, Identity, and the Body: Women's Autobiographical Practices in the Twentieth Century. Bloomington: Indiana University Press.

Smith, S., \& Watson, J. (2010). Reading Autobiography: A Guide for Interpreting Life Narratives. Minneapolis: U of Minnesota Press.

Sommer, D. (1988). Not Just a Personal Story: Women's Testimony and the Plural Self.” In B. Brodzki \& C. Schenck (Ed.), Life/Lines Theorizing Women's Autobiography (pp. 107-130). London: Cornell University Press.

Soueif, A. (1994). In the Eye of the Sun. New York: Vintage Books.

Taha, I. (2000). The Power of the Title: Why Have You Left the Horse Alone by Mahmoud Darwish. Journal of Arabic and Islamic Studies, 3, 66-83. Retrieved from http://www.lancaster.ac.uk/jais/volume/docs/vol3/v3_4_taha.htm

Van Leeuwen, R. (1998). Autobiography, Travelogue and Identity. In R. Ostle, E. Moor \& S. Wild (Ed.), Writing the Self: Autobiographical Writing in Modern Arabic Literature. London: Saqi Books.

Werbner, P. (2015). Introduction: The Dialectics of Cultural Hybridity. In P. Werbner et al. (Eds.), Debating Cultural Hybridity: Multicultural Identities and The Politics of anti-Racism (pp. 1-26). London: Zed Books. https://doi.org/10.2307/j.ctt183p51f.7

\section{Copyrights}

Copyright for this article is retained by the author, with first publication rights granted to the journal.

This is an open-access article distributed under the terms and conditions of the Creative Commons Attribution license (http://creativecommons.org/licenses/by/4.0/). 